\title{
Deinococcus aerius sp. nov., isolated from the high atmosphere
}

\author{
Yinjie Yang, ${ }^{1}$ Takashi Itoh, ${ }^{2}$ Shin-ichi Yokobori, ${ }^{1}$ Shiho Itahashi, ${ }^{1}$ \\ Haruo Shimada, ${ }^{1}$ Katsuya Satoh, ${ }^{3}$ Hirofumi Ohba, ${ }^{3}$ Issay Narumi ${ }^{3}$ \\ and Akihiko Yamagishi ${ }^{1}$ \\ 1Department of Molecular Biology, Tokyo University of Pharmacy and Life Science, Hachioji, Tokyo \\ 192-0392, Japan \\ 2Japan Collection of Microorganisms, RIKEN BioResource Center, 2-1 Hirosawa, Wako, Saitama \\ 351-0198, Japan \\ ${ }^{3}$ Quantum Beam Science Directorate, Japan Atomic Energy Agency, Takasaki 370-1292, Japan
}

Correspondence

Akihiko Yamagishi

yamagish@Is.toyaku.ac.jp
The genus Deinococcus was created in 1981 to accommodate radiation-resistant cocci exemplified by 'Micrococcus radiodurans' (Brooks \& Murray, 1981). Although one of the species, Deinococcus erythromyxa, has been transferred to the genus Kocuria (Rainey et al., 1997), the number of species in the genus Deinococcus has increased to 30 at the time of writing (Callegan et al., 2008). Airborne bacteria of the genus Deinococcus were first isolated as a contaminant from a hospital (Deinococcus radiodurans strain SARK) (Murray \& Robinow, 1958). Another Deinococcus-like micro-organism was later isolated from indoor air dust (Christensen \& Kristensen, 1981). Recently, Deinococcus cellulosilyticus was isolated from an air sample from an island (Weon et al., 2007). Here we report the characterization of a novel Deinococcus strain, designated TR0125 ${ }^{\mathrm{T}}$, isolated from the high atmosphere.

The GenBank/EMBL/DDBJ accession number for the $16 \mathrm{~S}$ rRNA gene sequence of strain TR0125 ${ }^{\top}$ is AB087288.

Tables showing the differential characteristics and fatty acid compositions of strain TRO125 $5^{\top}$ and the type strains of closely related Deinococcus species are available as supplementary material with the online version of this paper.
Air dust at various high altitudes above the main island of Japan was collected on membrane filters (type HA: diameter $47 \mathrm{~mm}$, pore size $0.45 \mu \mathrm{m}$; Millipore) using an ADS1 air sampler (Japan Machinery Co.) loaded on an aircraft (Gulfstream-2; Diamond Air Service). After sampling, the membrane filters were placed on mTGE agar composed of Difco mTGE broth $\left(1^{-1}\right.$ : beef extract, $6.0 \mathrm{~g}$; tryptone, $10.0 \mathrm{~g}$; glucose, $2.0 \mathrm{~g}$ ) plus Difco Bacto agar $\left(15 \mathrm{~g} \mathrm{l}^{-1}\right)$, and incubated at $30{ }^{\circ} \mathrm{C}$ for 2 weeks. Strain TR $0125^{\mathrm{T}}$ was isolated from a sample collected at an altitude of $0.8-5.8 \mathrm{~km}$.

Unless stated otherwise, bacterial cells used for biochemical and molecular studies were obtained by cultivation in mTGE broth. Growth temperatures were determined by spreading exponentially grown cells on mTGE agar, followed by incubation at $4,10,15$ and $47{ }^{\circ} \mathrm{C}$ and at specific temperatures from 20 to $45{ }^{\circ} \mathrm{C}$ for 2 weeks, and checking the development of colonies on the plates. Gram staining, and cell morphology and motility were examined under a microscope (Olympus BX-FLA). For scanning electron microscopy, bacterial cells were placed on a plastic sheet coated with poly-L-lysine and fixed with $2 \%$ 
glutaraldehyde. The preparations were then dehydrated in ethanol, critical-point dried, coated with metallic gold and examined in a low vacuum JSM-5800LV microscope (JEOL) operated at $15 \mathrm{kV}$.

Gamma-radiation resistance of strain TR $0125^{\mathrm{T}}$ was determined as described by Satoh et al. (2006). D. radiodurans ATCC $13939^{\mathrm{T}}$ was used as a control strain. Strains TR0125 $5^{\mathrm{T}}$ and ATCC $13939^{\mathrm{T}}$ were grown in mTGE broth at $30{ }^{\circ} \mathrm{C}$ to early stationary phase. Cells were harvested by centrifugation at $5000 \mathrm{~g}, 4{ }^{\circ} \mathrm{C}$ for $5 \mathrm{~min}$, washed twice with $10 \mathrm{mM}$ sodium phosphate buffer $(\mathrm{pH} 7.0)$ and resuspended in the same buffer. Aliquots $(100 \mu \mathrm{l})$ of the cell suspension were dispensed into test tubes and irradiated at room temperature for $5.5 \mathrm{~h}$ with ${ }^{60} \mathrm{Co}$ gamma-rays at dose rates of $0.37-1.45 \mathrm{kGy} \mathrm{h}^{-1}$ that were regulated by changing the distance of the samples from the gamma-ray source. Serial dilutions of the irradiated suspension and a nonirradiated control were plated on mTGE agar in triplicate. UV survival experiments were carried out according to the methods described by Miller (1992) and Arrage et al. (1993). D. radiodurans JCM 6273 and ATCC $13939^{\mathrm{T}}$ were used as control strains. Percentage survival was calculated as colony counts of irradiated cells divided by those of unirradiated control cells, multiplied by 100 . The $D_{10}$ value (radiation dose that reduced the number of cells to $10 \%$ of the original number) was calculated from the survival curve. Desiccation resistance of strain TR $0125^{\mathrm{T}}$ and the control strains ATCC $13939^{\mathrm{T}}$ and Escherichia coli MG1665 wild-type was determined according to the method of Callegan et al. (2008).

Peptidoglycan was prepared and the amino acids were analysed by using the methods described by Komagata \& Suzuki (1987). The fatty acid composition was analysed by $\mathrm{NCIMB}$, Japan. Bacterial cultures were grown at $28^{\circ} \mathrm{C}$ for 3 days. Methyl ester mixtures were prepared by using saponification, methylation and extraction (Kuykendall et al., 1988), and separated by using a gas chromatograph according to the operation manual (version 6) of the Sherlock Microbial Identification System (version 3.00B; MIDI). Identification and quantification of the methyl esters were conducted by using TSBA (version 4.0) of MIS Standard Libraries (MIDI). Menaquinones were extracted and determined according to Tindall (1989) and Shimada et al. (2001). Menaquinone-8 from strain ATCC $13939^{\mathrm{T}}$ and a commercial menaquinone-7 standard (Wako) were used as controls. Catalase, oxidase, $\beta$-galactosidase and hydrolysis and nitrate reduction tests were conducted according to the methods described by Barrow \& Feltham (1993). Singlecarbon-source assimilation studies were performed by using the methods described in the paper characterizing Deinococcus apachensis (Rainey et al., 2005). Growth was examined visually on agar plates incubated at $30{ }^{\circ} \mathrm{C}$ for 2 weeks. Plates without a carbon source were used as negative controls. mTGE plates were used as positive controls.

The DNA $\mathrm{G}+\mathrm{C}$ content was determined by using the method of Mesbah et al. (1989) with minor modifications.
DNA was isolated using a Blood \& Cell Culture DNA kit (Qiagen). E. coli W3110 wild-type and D. radiodurans ATCC $13939^{\mathrm{T}}$ were used as controls. For complete hydrolysis of DNA, $25 \mu \mathrm{l}$ of a solution containing $2-5 \mu \mathrm{g}$ DNA in a $1.5 \mathrm{ml}$ microfuge tube was heated in boiling water for $5 \mathrm{~min}$ and then rapidly cooled on ice, then $25 \mu \mathrm{l}$

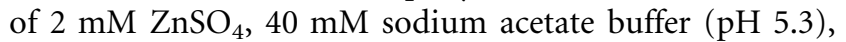
$20 \mu \mathrm{l}$ sterilized ultrapure water and $5 \mu \mathrm{l} 1$ nuclease $(20 \mathrm{U}$ $\mathrm{ml}^{-1}$ ) were added. After incubation for $2 \mathrm{~h}$ at $37^{\circ} \mathrm{C}, 2.5 \mu \mathrm{l}$ $0.1 \mathrm{M}$ glycine buffer ( $\mathrm{pH} 10.4$ ) and $6 \mu$ l bovine intestinal mucosa alkaline phosphatase $\left(0.35 \mathrm{U} \mathrm{ml}^{-1}\right)$ were added. The sample was then incubated overnight at $37{ }^{\circ} \mathrm{C}$ and stored at $4{ }^{\circ} \mathrm{C}$ until analysis. A $10 \mu \mathrm{l}$ sample was applied to an HPLC (Shimadzu LC-10Avp) equipped with a Capcell Pak C18 UG120 S-5 $\mu \mathrm{m}$ column (Shiseido) and a UV detector at $270 \mathrm{~nm}$, and analysed at a flow rate of $1.0 \mathrm{ml} \mathrm{min}{ }^{-1}$ at $40{ }^{\circ} \mathrm{C}$. The solvent used was $20 \mathrm{mM}$ $\mathrm{KH}_{2} \mathrm{PO}_{4}$ : HPLC-grade acetonitrile (70:1, by vol.).

Genomic DNA was extracted and purified using a FastDNA kit (BIO101). A 16S rRNA gene fragment (corresponding to E. coli nucleotides 10-1500) was amplified by PCR with primers EU 10F (5'-AGAGTTTGATCCTGGCTCAG- $3^{\prime}$ ) and EU 1500R (5'-GGTTACCTTGTTACGACTT-3') (Takami et al., 1999). The PCR products were cloned into pCR2.1TOPO (Invitrogen). The sequences were determined using an ABI Big Dye Terminator Cycle Sequencing FS Ready Reaction kit on an ABI PRISM 377 DNA Sequencing system (Applied Biosystems). The 16S rRNA gene sequences of closely related species were searched using the BLAST algorithm (BLASTN). The partial 16S rRNA gene sequences were aligned for phylogenetic analysis using CLUSTAL_X 1.83 software with the sequences of type strains of recognized Deinococcus species. The phylogenetic tree was constructed by using the maximum-likelihood method with TREEFINDER software (Jobb et al., 2004) under the GTR + I+G model selected by using the program MODELLTEST. Bootstrap analysis (1000 pseudoresamplings) was performed to obtain the bootstrap probability of each node. $16 \mathrm{~S}$ rRNA gene sequence similarity values between strain TR $0125^{\mathrm{T}}$ and the type strains of two closely related species (D. geothermalis and D. apachensis) were calculated using BLAST 2 sequences (Tatusova \& Madden, 1999) on the NCBI website.

Cells of strain TR $0125^{\mathrm{T}}$ were non-spore-forming, nonmotile, spherical and 1.0-1.5 $\mu \mathrm{m}$ in diameter, and occurred as single cells, or in pairs, tetrads or clusters (Fig. 1). Gramstaining yielded a positive reaction. Colonies on mTGE agar were circular, convex, shiny and orange. The edges of the colonies formed were wavy and smooth. Strain TR $0125^{\mathrm{T}}$ grew at $15-45{ }^{\circ} \mathrm{C}$. The optimum growth temperature range was $25-30{ }^{\circ} \mathrm{C}$. No growth occurred at 4,10 or $47^{\circ} \mathrm{C}$. Strain TR $0125^{\mathrm{T}}$ was catalase-, oxidase-, $\beta$-galactosidase- and alkaline phosphatase-positive and hydrolysed aesculin. The strain did not reduce nitrate to nitrite. Tests for urease, arginine dihydrolase, ornithine decarboxylase, $\beta$-glucuronidase, arginine arylamidase and pyrrolidone 


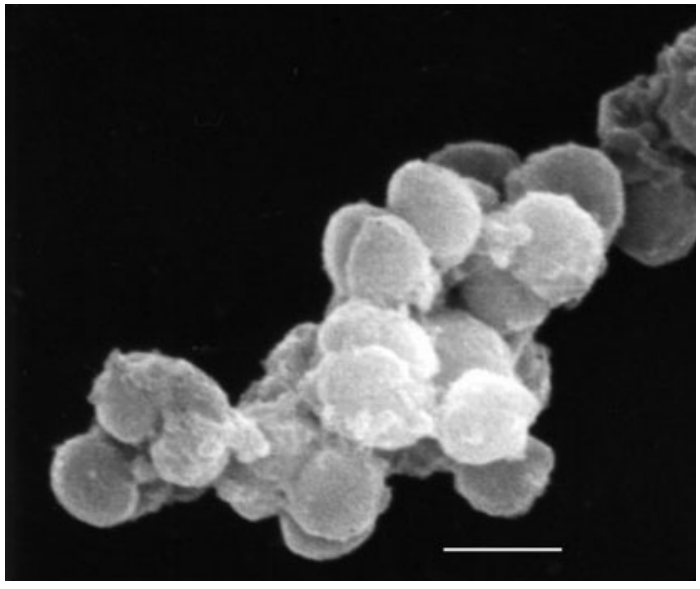

Fig. 1. Scanning electron micrograph showing the morphology of cells of strain TR0125 $5^{\mathrm{T}}$. Bar, $1 \mu \mathrm{m}$. arylamidase were negative. Strain TR0125 $5^{\mathrm{T}}$ was unable to utilize the following carbon sources: glucose, fructose, mannose, rhamnose, ribose, xylose, lactose, trehalose, melibiose, lactate, malate, aspartate, alanine, asparagine, glutamine, glycine, galactose, cellobiose, sorbose or acetate. Arabinose, glucosamine, ornithine, glutamate, maltose, sucrose, proline, raffinose, cysteine, lysine and methionine were utilized. Strain TR0125 $5^{\mathrm{T}}$ exhibited higher UVresistance, evaluated by $D_{10}$ values (strain $\mathrm{TR} 0125^{\mathrm{T}}$, $1200 \mathrm{~J} \mathrm{~m}^{-2}$ ), than D. radiodurans strains (JCM 6273, $860 \mathrm{~J} \mathrm{~m}^{-2}$; ATCC $13939^{\mathrm{T}}, 870 \mathrm{~J} \mathrm{~m}^{-2}$ ). The strain exhibited lower resistance to gamma radiation than $D$. radiodurans ATCC $13939^{\mathrm{T}}\left(D_{10}\right.$ values for strains TR0125 $5^{\mathrm{T}}$ and ATCC $13939^{\mathrm{T}}$ were 4.9 and $6.7 \mathrm{kGy}$, respectively). Desiccation resistance of strain TR0125 $5^{\mathrm{T}}$ was also lower than that of strain ATCC $13939^{\mathrm{T}}$, but was much higher than that of $E$. coli. Surviving fractions after desiccation for 6 weeks were $32 \%, 24 \%$ and 0 for strains ATCC $13939^{\mathrm{T}}$, TR0125 $5^{\mathrm{T}}$ and

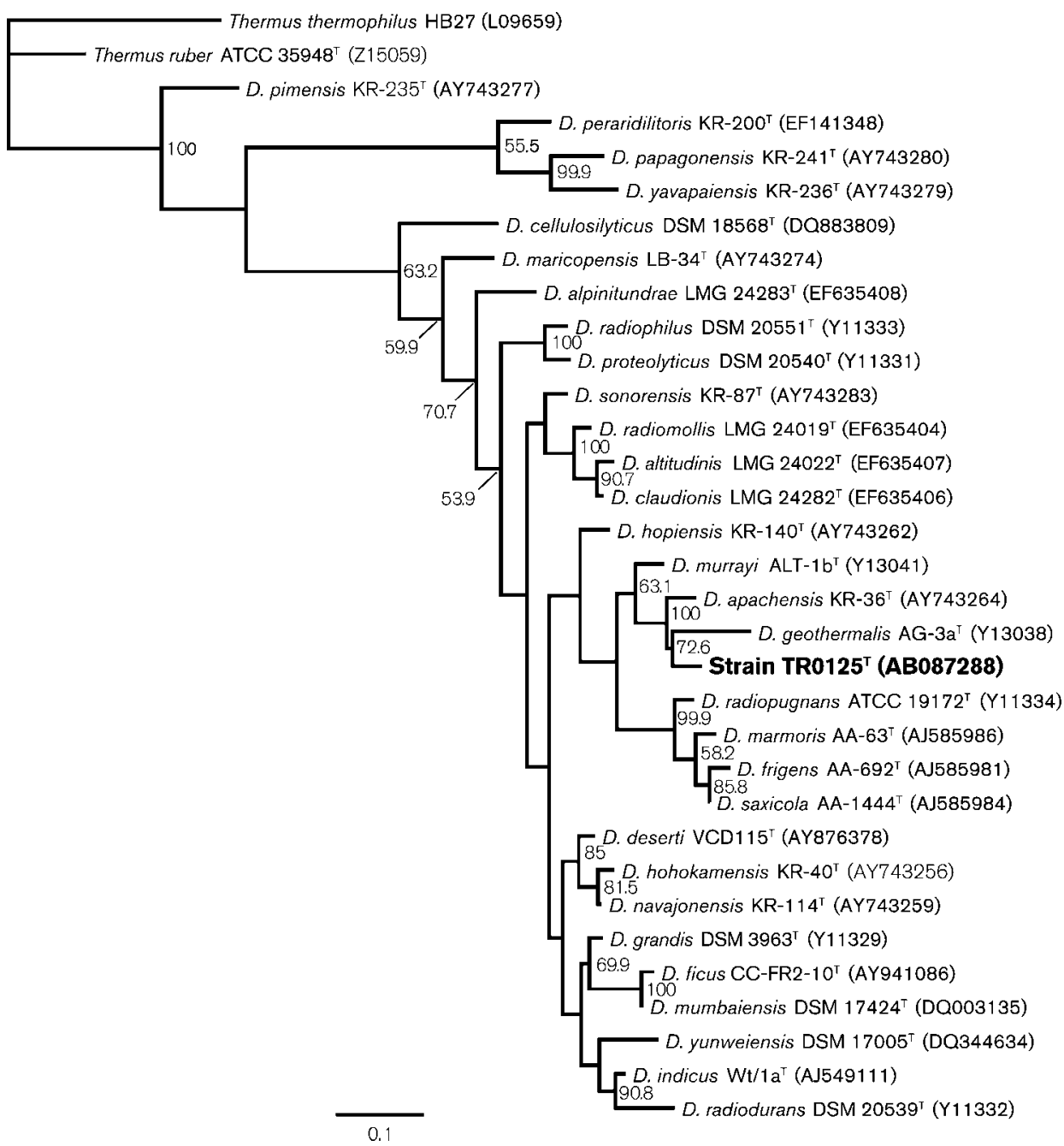

Fig. 2. Phylogenetic tree showing the relationship of strain TR0125 $5^{\top}$ to closely related species. Thermus ruber ATCC $35948^{\top}$ and Thermus thermophilus HB27 were used as an outgroup. Bootstrap probabilities of each node greater than $50 \%$ are shown. Bar, 0.1 substitutions per site. 
E. coli, respectively. Compared with D. radiodurans ATCC $13939^{\mathrm{T}}$, strain $\mathrm{TR} 0125^{\mathrm{T}}$ formed rigid cell pellets and desiccated cell aggregates that were harder to evenly resuspend during experiments.

The predominant fatty acids detected were branched-chain, iso- $\mathrm{C}_{17: 0}(23.5 \%)$, iso- $\mathrm{C}_{17: 1} \omega 9 c(16.3 \%)$ and iso- $\mathrm{C}_{15: 0}$ $(15.7 \%)$. The major peptidoglycan amino acids were Dglutamic acid, glycine, D-alanine, L-alanine and ornithine (molar ratio of $1: 2: 1: 1: 1$ ). The major menaquinone was MK-8. The DNA G $+\mathrm{C}$ content was $70.5 \mathrm{~mol} \%$. The BLAST search indicated that strain $\mathrm{TR} 0125^{\mathrm{T}}$ was most closely related to members of the genus Deinococcus. Strain TR0125 $5^{\mathrm{T}}$ showed 95.7 and $92.3 \% 16 \mathrm{~S}$ rRNA gene sequence similarities to the type strains of $D$. apachensis and $D$. geothermalis, respectively.

The 16S rRNA gene-based phylogenetic analysis showed that strain TR0125 $5^{\mathrm{T}}$ fell in the radiation of the Deinococcus cluster (Fig. 2). In addition, its cell morphology, high DNA $\mathrm{G}+\mathrm{C}$ content, desiccation tolerance, gamma- and UVresistance were also consistent with properties reported of recognized Deinococcus species. Among the hitherto recognized Deinococcus species, strain $\mathrm{TR}_{0125^{\mathrm{T}}}$ was relatively closer to the type strains of $D$. apachensis and D. geothermalis. The pairwise similarity values of the $16 \mathrm{~S}$ rRNA gene sequences among the three strains were not more than $97 \%$. In the phylogenetic tree, strain TR $0125^{\mathrm{T}}$ was further separated from $D$. apachensis than from $D$. geothermalis, indicating that strain $\mathrm{TR} 0125^{\mathrm{T}}$ was not a member of these two Deinococcus species. In addition, there were phenotypic differences between strain TR0125 and the two strains as shown in Supplementary Tables S1 and S2 (available in IJSEM Online). Therefore, strain TR $0125^{\mathrm{T}}$ is considered to represent a novel species of the genus Deinococcus, for which the name Deinococcus aerius sp. nov. is proposed.

\section{Description of Deinococcus aerius sp. nov.}

Deinococcus aerius (a.e'ri.us. L. masc. adj. aerius belonging to the air, referring to the isolation site of the type strain).

Colonies are circular, convex, orange-pigmented (nonfluorescent) and shiny with smooth edges. Cells are spherical, $1.0-1.5 \mu \mathrm{m}$ in diameter, aerobic, non-sporeforming and non-motile. Optimum temperature range for growth in mTGE broth is $25-30{ }^{\circ} \mathrm{C}$. Cells typically grow singly, and in pairs, tetrads and clusters and are resistant to desiccation, and gamma and UV radiation. Major fatty acids are iso- $C_{17: 0}$, iso- $C_{17: 1} \omega 9 c$ and iso- $C_{15: 0}$. Major peptidoglycan amino acids are D-glutamic acid, glycine, Dalanine, L-alanine and ornithine. Catalase- and oxidasepositive. Positive for alkaline phosphatase and $\beta$-galactosidase activities and hydrolysis of aesculin, but negative for reduction of nitrate to nitrite. L-Arabinose, glucosamine, ornithine, glutamate, maltose, sucrose, proline, raffinose, cysteine, lysine and methionine are utilized as carbon sources. The DNA $\mathrm{G}+\mathrm{C}$ content of the type strain is $70.5 \mathrm{~mol} \%$.
The type strain, $\mathrm{TR}_{0125^{\mathrm{T}}}\left(=\mathrm{JCM} 11750^{\mathrm{T}}=\mathrm{DSM} 21212^{\mathrm{T}}\right)$, was isolated from an air sample collected from the high atmosphere, Japan.

\section{Acknowledgements}

We are grateful to the crew of the Diamond Air Service Co. for their technical assistance in the sampling experiment. Y.Y. received a scholarship from the Hasegawa International Scholarship Foundation. This work was supported by Ground Research for Space Utilization Program promoted by the National Space Development Agency of Japan and Japan Space Forum.

\section{References}

Arrage, A. A., Phelps, T. J., Benoit, R. E., Palumbo, A. V. \& White, D. C. (1993). Bacterial sensitivity to UV light as a model for ionizing radiation resistance. J Microbiol Methods 18, 127-136.

Barrow, G. I. \& Feltham, R. K. A. (1993). Cowan and Steel's Manual for the Identification of Medical Bacteria, 3rd edn. Cambridge: Cambridge University Press.

Brooks, B. W. \& Murray, R. G. E. (1981). Nomenclature for "Micrococcus radiodurans" and other radiation-resistant cocci: Deinococcaceae fam. nov. and Deinococcus gen. nov., including five species. Int J Syst Bacteriol 31, 353-360.

Callegan, R. P., Nobre, M. F., McTernan, P. M., Battista, J. R., NavarroGonzalez, R., McKay, C. P., da Costa, M. S. \& Rainey, F. A. (2008). Description of four novel psychrophilic, ionizing radiation-sensitive Deinococcus species from alpine environments. Int $J$ Syst Evol Microbiol 58, 1252-1258.

Christensen, E. A. \& Kristensen, H. (1981). Radiation-resistance of micro-organisms from air in clean premises. Acta Pathol Microbiol Scand $[B]$ 89, 293-301.

Jobb, G., von Haeseler, A. \& Strimmer, K. (2004). TREEFINDER: a powerful graphical analysis environment for molecular phylogenetics. BMC Evol Biol 4, 18.

Komagata, K. \& Suzuki, K. I. (1987). Lipid and cell wall analysis in bacterial systematics. In Methods in Microbiology, pp. 161-207. Edited by R. R. Colwell \& R. Grigorova. London: Academic Press.

Kuykendall, L. D., Roy, M. A., O'Neill, J. J. \& Devine, T. E. (1988). Fatty acids, antibiotic resistance, and deoxyribonucleic acid homology groups of Bradyrhizobium japonicum. Int J Syst Bacteriol 38, 358-361.

Mesbah, M., Premachandran, U. \& Whitman, W. B. (1989). Precise measurement of the $\mathrm{G}+\mathrm{C}$ content of deoxyribonucleic acid by highperformance liquid chromatography. Int J Syst Bacteriol 39, 159-167.

Miller, J. H. (1992). A Short Course in Bacterial Genetics: a Laboratory Manual and Handbook for Escherichia coli. Cold Spring Harbor, NY: Cold Spring Harbor Laboratory.

Murray, R. G. E. \& Robinow, C. F. (1958). Cytological studies of a tetrad-forming coccus, 7th edn. Stockholm: Proc Intern Congr Microbiol pp. 427-428.

Rainey, F. A., Nobre, M. F., Schumann, P., Stackebrandt, E. \& da Costa, M. S. (1997). Phylogenetic diversity of the deinococci as determined by $16 \mathrm{~S}$ ribosomal DNA sequence comparison. Int J Syst Bacteriol 47, 510-514.

Rainey, F. A., Ray, K., Ferreira, M., Gatz, B. Z., Nobre, M. F., Bagaley, D., Rash, B. A., Park, M. J., Earl, A. M. \& other authors (2005). Extensive diversity of ionizing-radiation-resistant bacteria recovered from Sonoran Desert soil and description of nine new species of the genus Deinococcus obtained from a single soil sample. Appl Environ Microbiol 71, 5225-5235. 
Satoh, K., Ohba, H., Sghaier, H. \& Narumi, I. (2006). Downregulation of radioresistance by LexA2 in Deinococcus radiodurans. Microbiology 152, 3217-3226.

Shimada, H., Shida, Y., Nemoto, N., Oshima, T. \& Yamagishi, A. (2001). Quinone profiles of Thermoplasma acidophilum HO-62. J Bacteriol 183, 1462-1465.

Takami, H., Kobata, K., Nagahama, T., Kobayashi, H., Inoue, A. \& Horikoshi, K. (1999). Biodiversity in deep-sea sites located near the south part of Japan. Extremophiles 3, 97-102.
Tatusova, T. A. \& Madden, T. L. (1999). BLAST 2 sequences, a new tool for comparing protein and nucleotide sequences. FEMS Microbiol Lett 174, 247-250.

Tindall, B. J. (1989). Fully saturated menaquinones in the archaebacterium Pyrobaculum islandicum. FEMS Microbiol Lett 60, 251-254.

Weon, H. Y., Kim, B. Y., Schumann, P., Son, J. A., Jang, J., Go, S. J. \& Kwon, S. W. (2007). Deinococcus cellulosilyticus sp. nov., isolated from air. Int J Syst Evol Microbiol 57, 1685-1688. 